medRxiv preprint doi: https://doi.org/10.1101/2021.05.25.21257766; this version posted July 25 , 2021 . The copyright holder for this preprint (which was not certified by peer review) is the author/funder, who has granted medRxiv a license to display the preprint in perpetuity. It is made available under a CC-BY-NC-ND 4.0 International license .

\title{
Frailty variation models for susceptibility and exposure to SARS-CoV-2
}

\author{
M. Gabriela M. Gomes
}

Department of Mathematics and Statistics, University of Strathclyde, Glasgow, UK, and Centro de Matemática e Aplicações, Faculdade de Ciências e Tecnologia, Universidade Nova de Lisboa, Caparica, Portugal

E-mail: Gabriela.Gomes@strath.ac.uk

Marcelo U. Ferreira

Institute of Biomedical Sciences, University of São Paulo, São Paulo, Brazil.

E-mail: muferrei@usp.br

Maria Chikina

Department of Computational and Systems Biology, University of Pittsburgh, PA, USA.

E-mail: mchikina@pitt.edu

Wesley Pegden

Department of Mathematical Sciences, Carnegie Mellon University, Pittsburgh, PA, USA.

E-mail:wes@math.cmu.edu

Ricardo Aguas

Centre for Tropical Medicine and Global Health, Nuffield Department of Medicine, University of Oxford, Oxford, UK.

E-mail: Ricardo@tropmedres.ac

\begin{abstract}
Summary. Individual variation in susceptibility and exposure is subject to selection by force of infection, accelerating the natural acquisition of immunity, and reducing herd immunity thresholds and epidemic final sizes. This is a manifestation of a wider population phenomenon known as "frailty variation" in demography. Despite this theoretical understanding, public health policies continue to be guided by mathematical models that leave out most of the relevant variation and as a result inflate projected infection burdens. Here we focus on the trajectories of the coronavirus disease (COVID-19) pandemic in England and Scotland. We fit models to series of daily deaths and estimate relevant epidemiological parameters, including coefficients of variation which we find in agreement with direct measurements based on published contact surveys. Our estimates are robust to whether the data series encompass one or two pandemic waves. We conclude that herd immunity thresholds are being reached with a larger contribution of vaccination in Scotland than in England, where naturally acquired immunity is higher. These results are relevant to global vaccination policies.
\end{abstract}


medRxiv preprint doi: https://doi.org/10.1101/2021.05.25.21257766; this version posted July 25, 2021. The copyright holder for this preprint

(which was not certified by peer review) is the author/funder, who has granted medRxiv a license to display the preprint in perpetuity.

It is made available under a CC-BY-NC-ND 4.0 International license.

\section{M. G. M. Gomes, M. U. Ferreira, M. Chikina, W. Pegden and R. Aguas}

\section{Introduction}

Almost 100 years ago, Kermack and McKendrick (Kermack and McKendrick 1927) and McKendrick (McKendrick 1939) fitted susceptible-infected-recovered (SIR) models to observed epidemics and alerted for the simplifying assumption "that all infected persons are equivalent, and that all susceptible persons are equally liable to acquire infection" (McKendrick 1939). In their fittings they adjust not only transmission parameters but also the size of the susceptible and exposed population at epidemic onset. Susceptible and exposed population sizes needed to be adjusted so their homogeneous models could fit the data.

Thirty years later, Gart (Gart 1968) admited that "it is difficult to define exactly the size of the population of susceptible hosts. In this instance the difficulty is associated with the heterogeneous nature of the population". The author divided the population in two groups, depending on their history of infection, and allowed much greater susceptibility in the group with no history. This did not seem sufficient to provide good fit to observed epidemics as the author adds "we assume that the first group is a homogeneous group of susceptibles, while the second is actually a mixture of immune and susceptible individuals". In (Gart 1971) the author extend the model to several susceptibility groups, and, more than a decade later decade later, (Ball 1985) compared a model with several susceptibility groups with the homogeneous version and described how homogeneity increases epidemic size. (Coutinho et al. 1999) expand the formalisms but conclude that "at present practical applications might be difficult". (Pastor-Satorras and Vespignani 2001) developed related formalisms to describe epidemics on contact networks.

Meanwhile, frailty variation had been formalised in demography (Vaupel et al. 1979) and introduced in practice in survival analysis (Aalen 1988) and non-communicable disease epidemiology (Aalen et al. 2015) to improve model fits and interpretation.

On the experimental front, (Dwyer et al. 1997) measured nonlinear relationships between transmission and densities of susceptible hosts, implying that the bilinear term in the classical SIR model may not be appropriate. The authors attributed this nonlinearity in transmission to heterogeneity in host susceptibility to infection which they estimated from the shapes of dose-response curves.

(Finkenstadt and Grenfell 2000) fitted a model with nonlinear relationships between transmission and density of susceptible hosts to an observed epidemic and estimated the exponent which they interpreting as representing heterogeneity in mixing. (Novozhilov 2008) derived the expressions for the exponents from explicit distributions of susceptibility.

Here we build on this history and analyse the coronavirus disease (COVID-19) with frailty variation models. The study is focused on England and Scotland, where infection was first detected in early 2020.

We use susceptible-exposed-infected-recovered (SEIR) models (Diekmann et al. 2013) incorporating distributions of individual susceptibility or exposure to infection (Ball 1985; Coutinho et al. 1999; Gomes et al. 2020; Katriel 2012; Novozhilov 2008). We use Bayesian inference to estimate the model parameters by fitting series of deaths while accounting for the combined effects of non-pharmaceutical interventions (NPIs), behavioural change, seasonality and viral evolution. We estimate coefficients of variation which are in agreement with direct measurements based on contact-pattern studies, e.g., (Mossong et al. 2008; 
medRxiv preprint doi: https://doi.org/10.1101/2021.05.25.21257766; this version posted July 25,2021 . The copyright holder for this preprint (which was not certified by peer review) is the author/funder, who has granted medRxiv a license to display the preprint in perpetuity.

It is made available under a CC-BY-NC-ND 4.0 International license.

Hens et al. 2009; Willem et al. 2012). We show that individual variation in susceptibility or exposure to infection can significantly affect model projections and should be accounted for to describe the dynamics of SARS-CoV-2.

\section{Mathematical models}

The basic compartmental SEIR model describing the transmission dynamics of SARSCoV-2 is represented diagrammatically in Fig. 1. Following (Gomes et al. 2020) the model accounts for individual variation in susceptibility or exposure to infection.

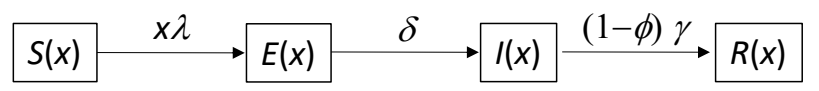

Fig. 1. Susceptible-exposed-infected-recovered (SEIR) compartmental model representing the transmission dynamics of SARS-CoV-2 in a heterogeneous host population.

\subsection{Individual variation in susceptibility to infection}

Let $x$ denote the individual susceptibility to infection in relation to the mean, which we describe by a gamma distribution $q(x)$ with mean $\int x q(x) d x=1$ and parametrised by a coefficient of variation, $C V=\sqrt{\int(x-1)^{2} q(x) d x}$. Susceptible individuals, $S(x)$, become exposed at a rate that depends on their susceptibility $x$ and on the average force of infection $\lambda$ which accounts for the total number of infectious individuals in the population over time. Upon exposure, susceptible individuals enter an incubation phase, $E(x)$, during which they gradually become infectious (Wei et al. 2020; To et al. 2020; Arons et al. 2020; He et al. 2020). The infectiousness in this phase is made to be half that in the following stage $(\rho=0.5)$, to which individuals transit within an average of 5.5 days $(\delta=1 / 5.5)$ (McAloon et al. 2020). The fully infectious state is denoted by $I(x)$. Infected individuals are eventually removed, on average approximately 4 days after becoming fully infectious $(\gamma=1 / 4)$ (Nishiura et al. 2020; Lauer et al. 2020; Li et al. 2020). A small fraction $\phi(x)$ die to COVID-19 while the remaining majority recover into $R(x)$ where they are noninfectious and temporarily resistant to reinfection due to acquired immunity. The model is represented diagrammatically in Fig. 1 and mathematically by the infinite system of ordinary differential equations:

$$
\begin{aligned}
\dot{S}(x) & =-\lambda x S(x), \\
\dot{E}(x) & =\lambda x S(x)-\delta E(x), \\
\dot{I}(x) & =\delta E(x)-\gamma I(x), \\
\dot{R}(x) & =[1-\phi(x)] \gamma I(x) .
\end{aligned}
$$

The average force of infection upon susceptible individuals in a population of size $N$ and transmission coefficient $\beta$ is defined by:

$$
\lambda=\frac{\beta}{N} \int[\rho E(x)+I(x)] d x .
$$


medRxiv preprint doi: https://doi.org/10.1101/2021.05.25.21257766; this version posted July 25, 2021. The copyright holder for this preprint (which was not certified by peer review) is the author/funder, who has granted medRxiv a license to display the preprint in perpetuity.

It is made available under a CC-BY-NC-ND 4.0 International license .

An epidemic is simulated by introducing a small seed of infectious individuals in a susceptible population. Initial growth of infected numbers is near exponential but decelerates as individuals are removed from the susceptible pool by infection and immunity. With variation in susceptibility, highly susceptible individuals tend to be infected earlier, leaving behind a residual pool of lower mean susceptibility. This selective depletion intensifies the deceleration of epidemic growth and gives an efficient head start to the acquisition of population immunity. Eventually the epidemic will subside and the herd immunity threshold, defining the percentage of the population that needs to be immune to reverse epidemic growth and prevent future waves, is lower when variation in susceptibility is higher.

The basic reproduction number, defined as the number of infections caused by an average infected individual in a totally susceptible population, is written for system (1)-(4) with force of infection (5) as:

$$
\mathcal{R}_{0}=\beta\left(\frac{\rho}{\delta}+\frac{1}{\gamma}\right) .
$$

This is a crude indicator of early transmissibility but its use quickly becomes cumbersome. Several factors, such as NPIs, human behaviour, seasonality and viral evolution, affect $\mathcal{R}_{0}$ in a time-dependent manner. We denote the resulting quantity by $\mathcal{R}_{\mathrm{c}}(t)=c(t) \cdot \mathcal{R}_{0}$, where $c(t)>0$ describes the basic risk of infection at time $t$ in relation to baseline.

In the estimation of $\mathcal{R}_{\mathrm{c}}(t)$ we assume a profile for $c(t)$ as illustrated in Fig. 2: $T_{0}$ is the time when $\mathcal{R}_{0}$ begins to show decrease due to behavioural change or seasonality; $L_{1}$ is the period of maximal contact restrictions due to lockdown (48 days in England, from 26 March to 12 May, and 66 days in Scotland, from 24 March to 28 May, 2020) and $c_{1} \leq 1$ is the value of $\mathcal{R}_{\mathrm{c}}(t)$ during $L_{1}$ in relation to the initial $\mathcal{R}_{0} ; T_{1}$ is the time elapsed between $T_{0}$ and $L_{1}$, over which transmission is allowed to decrease linearly. After $L_{1}$, contact restrictions are progressively relaxed and we allow transmission to begin a linear increase such that $c(t)$ reaches 1 in $T_{2}$ days, which may or may not be within the range of the study. Changes in other factors that affect transmission (such as seasonality or viral evolution) are inseparable from contact changes in this framework and are also accounted for by $c(t)$.

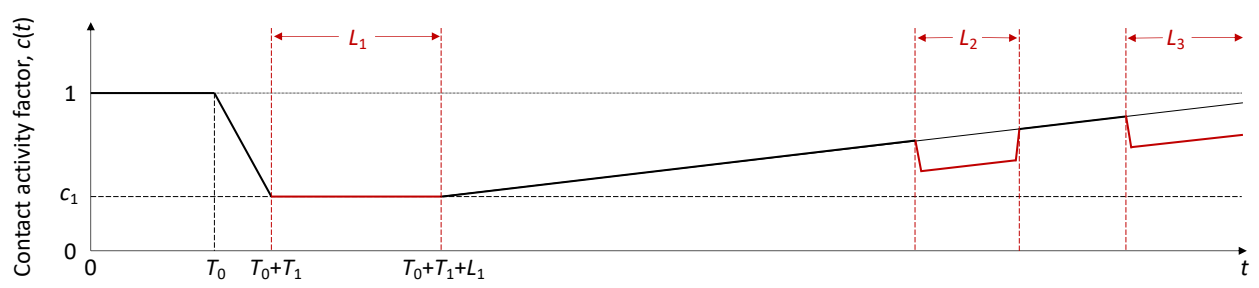

Fig. 2. Schematic illustration of factor $c(t)$ representing the combined effects of NPIs, seasonality and viral evolution on the reproduction number.

The model will be used to analyse COVID-19 deaths recorded over approximately 
one year. Mathematically this is constructed as:

$$
c_{0}(t)= \begin{cases}1, & \text { if } 0<t \leq T_{0} \\ 1-\left(1-c_{1}\right) \cdot \frac{\left(t-T_{0}\right)}{T_{1}}, & \text { if } T_{0}<t \leq T_{0}+T_{1} \\ c_{1}, & \text { if } T_{0}+T_{1}<t \leq T_{0}+T_{1}+L_{1} \\ 1-\left(1-c_{1}\right) \cdot \frac{\left(T_{0}+T_{1}+L_{1}+T_{2}-t\right)}{T_{2}}, & \text { otherwise. }\end{cases}
$$

Second and third lockdowns in the autumn and winter season are implemented more simply as a further reduction in transmission (by a factor $c_{2}$ ) over the stipulated time periods. Specifically:

$$
c(t)= \begin{cases}c_{2} \cdot c_{0}(t), & \text { if } t \in[5 \text { November } 2020,1 \text { December } 2020] \\ c_{0}(t), & \text { or } t \in[5 \text { January 2021, last data point }]\end{cases}
$$

A finite version of system (1)-(4) and (5) can be derived exactly (Novozhilov 2008):

$$
\begin{aligned}
\dot{S} & =-\beta(\rho E+I)\left(\frac{S}{N}\right)^{1+C V^{2}}, \\
\dot{E} & =\beta(\rho E+I)\left(\frac{S}{N}\right)^{1+C V^{2}}-\delta E \\
\dot{I} & =\delta E-\gamma I .
\end{aligned}
$$

If $\mathcal{R}_{0}$ had remained constant throughout the duration of the study, a herd immunity threshold (HIT) would be derived as in (Montalbán et al. 2020):

$$
\mathcal{H}_{0}=1-\left(\frac{1}{\mathcal{R}_{0}}\right)^{\frac{1}{1+C V^{2}}} .
$$

The expectation, however, is that $\mathcal{R}_{0}$ changes due to seasonal effects and viral evolution. These effects are currently inseparable from those of NPIs and behavioural change and, consequently, we cannot obtain a time-depend $\mathcal{R}_{0}$. Although our results for variable susceptibility models will be accompanied by HIT estimates calculated according to formula (12) we highlight that these refer to a virus as transmissible as the SARS-CoV-2 of early 2020. Once reliable estimates are available for evolving transmissibility, HIT estimates can be updated.

In reality, as infection spreads, the susceptible compartment $S$ is depleted and recovered individuals populate compartment $R$ where they are protected by acquired immunity. Eventually they lose that protection as immunity wanes or is evaded by new viral variants. This is omitted in this version of the model given our purpose to analyse data reported over one year when the frequency of reinfection has been relatively low in our study setting (Hall et al. 2021). In Supplementary Information, however, we formulate an extended model with reinfection to show that the addition does not change our conclusions. 
medRxiv preprint doi: https://doi.org/10.1101/2021.05.25.21257766; this version posted July 25,2021 . The copyright holder for this preprint (which was not certified by peer review) is the author/funder, who has granted medRxiv a license to display the preprint in perpetuity.

\subsection{Individual variation in exposure to infection}

In a directly transmitted infectious disease, such as COVID-19, variation in exposure to infection is primarily governed by patterns of connectivity among individuals. We incorporate this in system (1)-(4) assuming that individuals mix at random (Pastor-Satorras and Vespignani 2001; Miller et al. 2012). In a separate study we developed an assortative mixing version of the model adopted here and did not find the results of interest to change (Aguas et al. 2020). Under random mixing and heterogeneous connectivity, the force of infection is written as

$$
\lambda=\frac{\beta}{N} \frac{\int x[\rho E(x)+I(x)] d x}{\int x q(x) d x} .
$$

The basic reproduction number is

$$
\mathcal{R}_{0}=\left(1+C V^{2}\right) \beta\left(\frac{\rho}{\delta}+\frac{1}{\gamma}\right),
$$

and $\mathcal{R}_{\mathrm{c}}(t)=c(t) \cdot \mathcal{R}_{0}$ is as above.

As with variable susceptibility, model (1)-(4) with variable exposure (13) can be reduced to a 3 -dimensional system of ODEs:

$$
\begin{aligned}
\dot{S} & =-\left(1+C V^{2}\right) \beta(\rho E+I)\left(\frac{S}{N}\right)^{1+2 C V^{2}}, \\
\dot{E} & =\left(1+C V^{2}\right) \beta(\rho E+I)\left(\frac{S}{N}\right)^{1+2 C V^{2}}-\delta E, \\
\dot{I} & =\delta E-\gamma I,
\end{aligned}
$$

the effective reproduction number written as:

$$
\mathcal{R}_{\text {eff }}(t)=\mathcal{R}_{\mathrm{c}}(t)\left(\frac{S}{N}\right)^{1+2 C V^{2}},
$$

and the herd immunity threshold derived as in (Montalbán et al. 2020):

$$
\mathcal{H}_{0}=1-\left(\frac{1}{\mathcal{R}_{0}}\right)^{\frac{1}{1+2 C V^{2}}} .
$$

\section{Data}

We used publicly available epidemiological data from the UK coronavirus dashboard [https://coronavirus.data.gov.uk/] describing the unfolding of the SARS-CoV-2 epidemic, to estimate relevant transmission related parameters for the larger nations: England (56 million inhabitants) and Scotland (5.5 million). Namely, we collected datasets containing daily deaths (deaths within 28 days of positive test by date of death), $\left\{\left(k, \tilde{y}_{k}\right)\right\}_{k=1}^{n}$, where $k=1$ is the day when the cumulative moving average of death numbers exceeded $5 \cdot 10^{-8}$ of the population in both nations (10 March 2020). 
Model outputs would then be fitted to the raw series of daily deaths between 10 March 2020 and 1 February 2021 ( $n=329$ days in total) adopting an infection fatality ratio of $0.9 \%$ (Ward et al. 2021) throughout the study period and initial conditions:

$$
\begin{aligned}
& I(0)=\frac{\tilde{y}_{1+\eta}}{1-\exp (-I F R \cdot \gamma)}, \\
& E(0)=\frac{I(1)}{1-\exp (-\delta)}, \\
& S(0)=N-E(0)-I(0),
\end{aligned}
$$

where $\eta$ is the excess duration of a fatal infection relatively to non-fatal. In Supplementary Information we explore the sensitivity of the heterogeneous susceptibility results to changing the value of IFR.

\section{Model fitting and parameter estimation}

In order to preserve identifiability, we made five simplifying assumptions: (i) the infection fatality ratio (IFR) is constant throughout the study period; (ii) natural (seasonality and viral evolution) and interventional (NPI) modulators of the reproduction number are encapsulated into a single time varying parameter $c(t)$ as illustrated in Fig. 2; (iii) excess transmission from critically ill stages is negligible; (iv) reinfection is negligible; (v) vaccine effects are negligible during the fitted period, which in section 5.1 ends on 1 February 2021 (less than 1\% fully vaccinated in the UK) and in section 5.2 ends on 1 July 2020 (no vaccines were in use).

Parameter estimation was performed with the software MATLAB (MathWorks, Natick, MA) using the PESTO (Parameter EStimation TOolbox) package (Stapor et al. 2018). We assumed that the number of SARS-CoV-2 infections are Poisson distributed.

We try to reproduce the dynamics of COVID-19 deaths by estimating the set of parameters $\theta$ that maximises the log-likelihood (LL) of observing the daily numbers of reported deaths $Y$ :

$$
\begin{aligned}
L L^{E}\left(\theta \mid Y^{E}\right) & =-\sum_{k=1}^{n} y^{E}(k, \theta)+\sum_{k=1}^{n} \tilde{y}^{E}(k) \ln \left(y^{E}(k, \theta)\right)-\sum_{k=1}^{n} \ln \left(\tilde{y}^{E}(k) !\right), \\
L L^{S}\left(\theta \mid Y^{S}\right) & =-\sum_{k=1}^{n} y^{S}(k, \theta)+\sum_{k=1}^{n} \tilde{y}^{S}(k) \ln \left(y^{S}(k, \theta)\right)-\sum_{k=1}^{n} \ln \left(\tilde{y}^{S}(k) !\right), \\
L L(\theta \mid Y) & =L L^{E}\left(\theta \mid Y^{E}\right)+L L^{S}\left(\theta \mid Y^{S}\right),
\end{aligned}
$$

in which $y^{E}(k, \theta)$ and $y^{S}(k, \theta)$ are the simulated model output numbers of COVID-19 deaths at day $k$ in England and Scotland for the set of parameters $\theta, Y=\left\{\left(k, \tilde{y}_{k}^{E}\right)\right\}_{k=1}^{n}$ and $Y=\left\{\left(k, \tilde{y}_{k}^{S}\right)\right\}_{k=1}^{n}$ are the numbers of daily reported deaths, and $n$ is the total number of days included in the analysis.

The set of parameters to be estimated is:

$$
\theta=\left\{T_{0}^{E}, T_{0}^{S}, T_{2}^{E}, T_{2}^{S}, c_{1}, c_{2}, \eta, R_{0}^{E}, R_{0}^{S}, C V\right\} .
$$


medRxiv preprint doi: https://doi.org/10.1101/2021.05.25.21257766; this version posted July 25, 2021. The copyright holder for this preprint

(which was not certified by peer review) is the author/funder, who has granted medRxiv a license to display the preprint in perpetuity.

It is made available under a CC-BY-NC-ND 4.0 International license .

M. G. M. Gomes, M. U. Ferreira, M. Chikina, W. Pegden and R. Aguas

To ensure that the estimated maximum is a global maximum, we performed 50 multistart optimisations with initialisation parameters sampled from a Latin-Hypercube. The combination of parameters resulting in the maximal log-likelihood were used as a starting point for 100,000 Markov Chain Monte-Carlo iterations. From the resulting posterior distributions, we extracted the median estimates for each parameter and the respective $95 \%$ credible intervals. We used uniformly distributed priors with wide ranges.

We apply the outlined fitting procedure using both heterogeneity models (specifically individual variation in susceptibility to infection and individual variation in exposure to infection) as well as a homogeneity model where we set the coefficient of variation to zero $(C V=0)$. The Akaike information criterion (AIC) is then applied to select the best fitting model.

\section{Results and Discussion}

\subsection{Estimated parameters and herd immunity thresholds}

Variable susceptibility, variable connectivity and homogeneous models were fitted to series of COVID-19 death reported in England and Scotland until 1 February 2021. The fits are shown in Figs. 3, 4 and 5 (fitted data points in green), and the estimated parameters in Table 1. Maximum log-likelihoods are also displayed, as well as AIC scores for model selection. We conclude that variable susceptibility and variable connectivity models are better supported by the data (lower AIC in bold) than the homogeneous model as found previously (Aguas et al. 2020; Colombo et al. 2020). Variable connectivity is slightly better supported although the reality most likely combines the two forms of heterogeneity.

Given the estimated values for $\mathcal{R}_{0}$ and $C V$ we derive the herd immunity thresholds by natural infection by applying formulas (12) or (19) as appropriate, obtaining $\mathcal{H}_{0}=29 \%$ in England and $\mathcal{H}_{0}=31 \%$ in Scotland. If population immunity was to be acquired by random vaccination alone, selection would not play a role and HIT would be given by $1-1 / \mathcal{R}_{0}$, resulting in $71 \%$ in England and $73 \%$ in Scotland. In reality, both natural infection and vaccination contribute to population immunity, and HIT will be somewhere in between. The homogeneous model suggests $\mathcal{H}_{0}=73 \%$ in England and $\mathcal{H}_{0}=75 \%$ in Scotland, in agreement with conventional expectations (Kwok et al. 2020).

We then prolong model trajectories (dashed curves) over another 4 months (until 1 June 2021) to compare with data beyond the fitted period (yellow). All models project more deaths than observed, as expected given that the UK initiated a mass vaccination campaign in late 2020 which should start impacting the epidemic by February 2021. To illustrate this we simulate the effective immunisation of $8 \%$ of the unvaccinated population per month from February onwards (crude approximation for the UK programme, where $32 \%$ were fully vaccinated in the 4 -month period February-May) and depict the result by the red dashed curve in the figures. Agreement with data is visually good for the heterogeneous models but insufficient under homogeneity.

The most timely question is perhaps whether achieved population immunity is enough to prevent an exit wave as contact restrictions are lifted. To contribute towards an answers we plot the cumulative number of infections estimated by the model (blue) and find the percentage of the population infected by May 2021 to remain below HIT (more so 
medRxiv preprint doi: https://doi.org/10.1101/2021.05.25.21257766; this version posted July 25, 2021. The copyright holder for this preprint (which was not certified by peer review) is the author/funder, who has granted medRxiv a license to display the preprint in perpetuity.

It is made available under a CC-BY-NC-ND 4.0 International license.

in Scotland than in England). Hence without vaccination an exit wave might have been expected. To visualise its magnitude we include separate panels on the right where the model is run for 8 months, using as initial conditions the end conditions of the left panels and $\mathcal{R}_{\mathrm{c}}(t)=\mathcal{R}_{0}$. This is done without vaccination (heavy black) and with vaccination (effective immunisation of $8 \%$ per month; heavy red). We explore additional vaccination scenarios (thin curves), from top to bottom (in \% of unvaccinated population per month): $0.5,1,1.5,2,3,4,5,6,7$ (black); 9, 10, 11, 12, 13, 14, 15, 16 (red). We find $1-2 \%$ effective immunisation by the vaccines per month to be sufficient to prevent the exit wave over the first 8 months, according to the heterogeneous models. This is in stark contrast with the homogeneous scenario, which suggest that only a vaccination programme twice as efficient as the current (e.g., approximately $16 \%$ effective immunisation per month) would prevent the exit wave.

In supplementary Information we show that these results are robust to changing IFR (to $0.7 \%$ and $1.1 \%$ ) and including reinfection (with a risk of 0.1 (Hall et al. 2021) relative to the average risk of first infection). As expected, assuming a higher IFR results in lower HIT and assuming a lower IFR results in higher HIT. However, when we fit the model with a different IFR, all parameters readjust and the exit wave appears relatively invariant to IFR. The same happens when reinfection is included. The sensitivity analysis is presented for the heterogeneous susceptibility model but replication with heterogeneous connectivity and homogeneity showed similar robustness.

So far we have considered that $\mathcal{R}_{\mathrm{c}}(t)$ would always be contained below the original $\mathcal{R}_{0}$. Given current concerns that the virus may evolve towards higher transmissibility, such as the emergence of the B.1.1.7 variant (Volz et al. 2021; Davies et al. 2021; Richard et al. 2021), we replicate the above exploration of exit scenarios assuming 50\% higher transmissibility $\left(\mathcal{R}_{\mathrm{c}}(t)=1.5 \cdot \mathcal{R}_{0}\right)$ (Fig. 6). 
medRxiv preprint doi: https://doi.org/10.1101/2021.05.25.21257766; this version posted July 25, 2021. The copyright holder for this preprint (which was not certified by peer review) is the author/funder, who has granted medRxiv a license to display the preprint in perpetuity. It is made available under a CC-BY-NC-ND 4.0 International license .
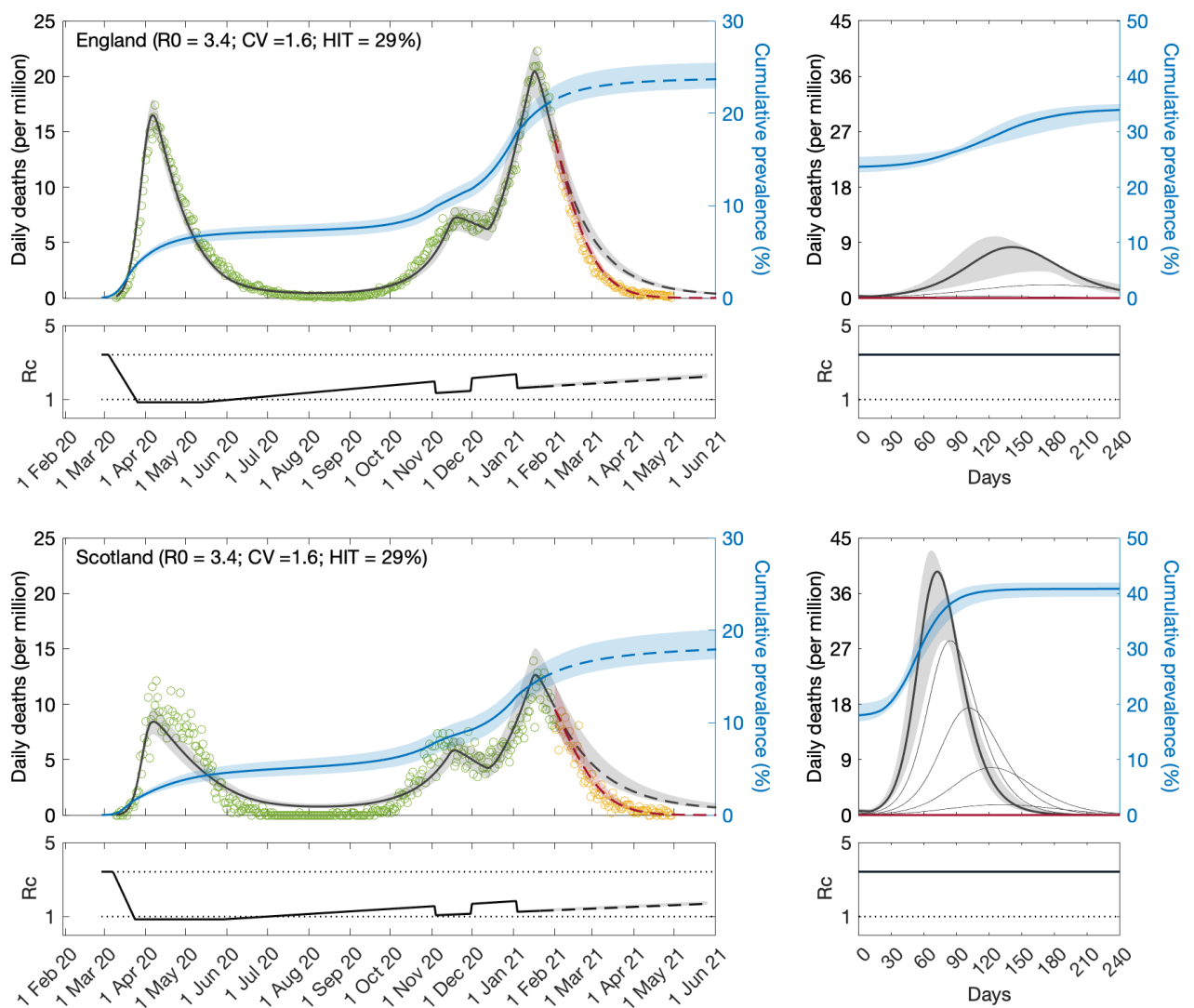

Fig. 3. SARS-CoV-2 transmission in England and Scotland with individual variation in susceptibility to infection. Susceptibility factors implemented as gamma distributions. Modelled trajectories of COVID-19 deaths (black and red curves) and cumulative percentage infected (blue). Dots are data for daily reported deaths: fitted (green); posterior to fitted time period (yellow). Basic reproduction numbers under control $\left(\mathcal{R}_{c}\right)$ are displayed on shallow panels underneath the main plots. Left panels represent fitted segments as solid curves and projected scenarios as dashed: without vaccination (black); with a vaccination programme that effectively immunises $8 \%$ of the unvaccinated population per month from February onwards (red). Right panels prolong those projections further in time assuming $\mathcal{R}_{\mathrm{c}}(t)=\mathcal{R}_{0}$ (heavier curves) and explore additional vaccination scenarios (thin curves), from top to bottom (in $\%$ of unvaccinated population per month): $0.5,1,1.5,2,3,4,5,6,7$ (black); $9,10,11,12,13,14,15,16$ (red). Inputed parameter values: $\delta=1 / 4$ per day; $\gamma=1 / 5.5$ per day; $\rho=0.5$; and infection fatality ratio IFR $=0.9 \%$. Inicial basic reproduction numbers, coefficients of variation and control parameters estimated by Bayesian inference (estimates in Table 1). Fitted curves represent best fitting trajectories and shades are $95 \%$ credible intervals generated from 100, 000 posterior samples. 
medRxiv preprint doi: https://doi.org/10.1101/2021.05.25.21257766; this version posted July 25, 2021. The copyright holder for this preprint (which was not certified by peer review) is the author/funder, who has granted medRxiv a license to display the preprint in perpetuity. It is made available under a CC-BY-NC-ND 4.0 International license.
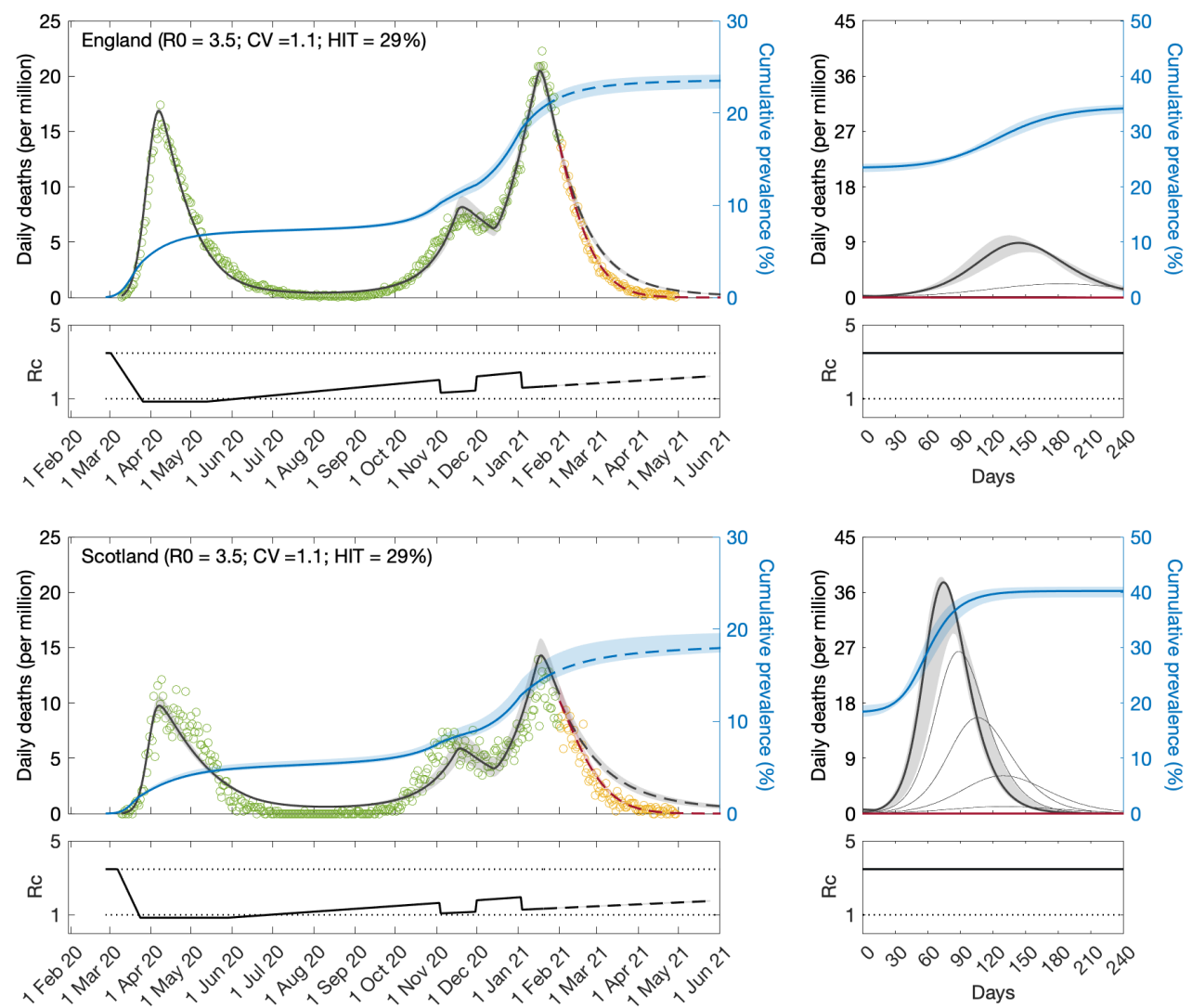

Fig. 4. SARS-CoV-2 transmission in England and Scotland with individual variation in exposure to infection. Connectivity factors implemented as gamma distributions. Modelled trajectories of COVID-19 deaths (black and red curves) and cumulative percentage infected (blue). Dots are data for daily reported deaths: fitted (green); posterior to fitted time period (yellow). Basic reproduction numbers under control $\left(\mathcal{R}_{\mathrm{c}}\right)$ are displayed on shallow panels underneath the main plots. Left panels represent fitted segments as solid curves and projected scenarios as dashed: without vaccination (black); with a vaccination programme that effectively immunises $8 \%$ of the unvaccinated population per month from February onwards (red). Right panels prolong those projections further in time assuming $\mathcal{R}_{\mathrm{c}}(t)=\mathcal{R}_{0}$ (heavier curves) and explore additional vaccination scenarios (thin curves), from top to bottom (in $\%$ of unvaccinated population per month): $0.5,1,1.5,2,3,4,5,6,7$ (black); $9,10,11,12,13,14,15,16$ (red). Inputed parameter values: $\delta=1 / 4$ per day; $\gamma=1 / 5.5$ per day; $\rho=0.5$; and infection fatality ratio IFR $=0.9 \%$. Inicial basic reproduction numbers, coefficients of variation and control parameters estimated by Bayesian inference (estimates in Table 1). Fitted curves represent best fitting trajectories and shades are 95\% credible intervals generated from 100, 000 posterior samples. 
medRxiv preprint doi: https://doi.org/10.1101/2021.05.25.21257766; this version posted July 25, 2021. The copyright holder for this preprint (which was not certified by peer review) is the author/funder, who has granted medRxiv a license to display the preprint in perpetuity. It is made available under a CC-BY-NC-ND 4.0 International license .
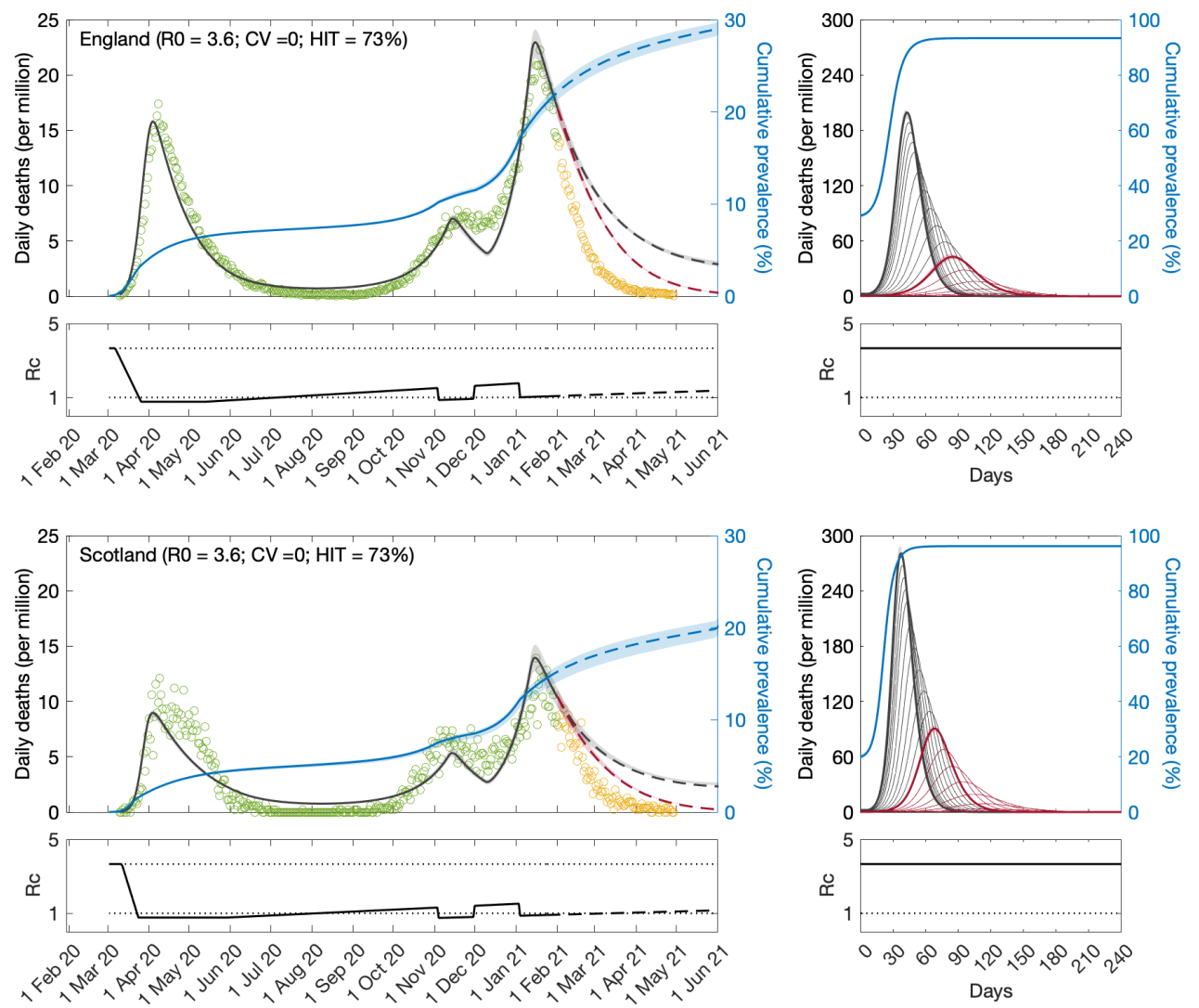

Fig. 5. SARS-CoV-2 transmission in England and Scotland under homogeneity. Modelled trajectories of COVID-19 deaths (black and red curves) and cumulative percentage infected (blue). Dots are data for daily reported deaths: fitted (green); posterior to fitted time period (yellow). Basic reproduction numbers under control $\left(\mathcal{R}_{c}\right)$ are displayed on shallow panels underneath the main plots. Left panels represent fitted segments as solid curves and projected scenarios as dashed: without vaccination (black); with a vaccination programme that effectively immunises $8 \%$ of the unvaccinated population per month from February onwards (red). Right panels prolong those projections further in time assuming $\mathcal{R}_{\mathrm{c}}(t)=\mathcal{R}_{0}$ (heavier curves) and explore additional vaccination scenarios (thin curves), from top to bottom (in $\%$ of unvaccinated population per month): $0.5,1,1.5,2,3,4,5,6,7$ (black); 9, 10, 11, 12, 13, 14, 15, 16 (red). Inputed parameter values: $\delta=1 / 4$ per day; $\gamma=1 / 5.5$ per day; $\rho=0.5$; and infection fatality ratio IFR $=0.9 \%$. Inicial basic reproduction numbers and control parameters estimated by Bayesian inference (estimates in Table 1). Fitted curves represent best fitting trajectories and shades are $95 \%$ credible intervals generated from 100, 000 posterior samples. 
medRxiv preprint doi: https://doi.org/10.1101/2021.05.25.21257766; this version posted July 25,2021 . The copyright holder for this preprint (which was not certified by peer review) is the author/funder, who has granted medRxiv a license to display the preprint in perpetuity.

It is made available under a CC-BY-NC-ND 4.0 International license .

Table 1. Model parameters estimated by Bayesian inference based on daily deaths until 1 February 2021. Model selection based on maximum log-likelihood (LL) and Akaike information criterion (AIC). Best fitting models have lower AIC scores. Infection fatality ratio, IFR $=0.9 \%$. $\mathcal{H}_{0}$, calculated from $\mathcal{R}_{0}$ and $C V$ using formulas (12) or (19), as appropriate.

\begin{tabular}{|c|c|c|c|c|c|c|}
\hline & \multicolumn{2}{|c|}{ Heterogeneous susceptibility } & \multicolumn{2}{|c|}{ Heterogeneous connectivity } & \multicolumn{2}{|c|}{ Homogeneous } \\
\hline & Median & $95 \%$ CI & Median & $95 \%$ CI & Median & $95 \% \mathrm{CI}$ \\
\hline \multicolumn{7}{|c|}{ Common parameters } \\
\hline$c_{1}$ & 0.25 & $(0.24,0.26)$ & 0.24 & $(0.24,0.25)$ & 0.21 & $(0.21,0.21)$ \\
\hline$c_{2}$ & 0.68 & $(0.67,0.73)$ & 0.65 & $(0.64,0.67)$ & 0.57 & $(0.57,0.57)$ \\
\hline$\eta$ & 11 & $(11,11)$ & 12 & $(12,12)$ & 8 & $(8,8)$ \\
\hline$C V$ & 1.59 & $(1.58,1.62)$ & 1.14 & $(1.12,1.17)$ & 0 & - \\
\hline \multicolumn{7}{|c|}{ England } \\
\hline$T_{0}$ & 5.13 & $(5.08,5.61)$ & 3.92 & $(3.87,3.95)$ & 4.56 & $(4.56,4.58)$ \\
\hline$T_{2}$ & 398.90 & $(396.50,400.14)$ & 389.50 & $(382.44,393.46)$ & 685.98 & $(685.47,686.80)$ \\
\hline $\mathcal{R}_{0}$ & 3.41 & $(3.35,3.45)$ & 3.47 & $(3.46,3.48)$ & 3.67 & $(3.67,3.68)$ \\
\hline $\mathcal{H}_{0}$ & $29 \%$ & $(28 \%, 30 \%)$ & $29 \%$ & $(28 \%, 30 \%)$ & $73 \%$ & $(73 \%, 73 \%)$ \\
\hline \multicolumn{7}{|c|}{ Scotland } \\
\hline$T_{0}$ & 8.53 & $(8.27,9.53)$ & 8.96 & $(8.43,9.61)$ & 9.07 & $(9.03,9.09)$ \\
\hline$T_{2}$ & 570.38 & $(557.91,581.11)$ & 518.79 & $(500.88,532.28)$ & 847.43 & $(845.30,848.62)$ \\
\hline $\mathcal{R}_{0}$ & 3.72 & $(3.60,3.77)$ & 3.72 & $(3.68,3.74)$ & 3.96 & $(3.96,3.97)$ \\
\hline $\mathcal{H}_{0}$ & $31 \%$ & $(30 \%, 32 \%)$ & $31 \%$ & $(30 \%, 31 \%)$ & $75 \%$ & $(75 \%, 75 \%)$ \\
\hline \multicolumn{7}{|c|}{ Model selection } \\
\hline LL & & -4214 & & -3712 & & -6079 \\
\hline $\mathrm{AIC}$ & & 8448 & & 7443 & & 12176 \\
\hline
\end{tabular}


medRxiv preprint doi: https://doi.org/10.1101/2021.05.25.21257766; this version posted July 25,2021 . The copyright holder for this preprint (which was not certified by peer review) is the author/funder, who has granted medRxiv a license to display the preprint in perpetuity.
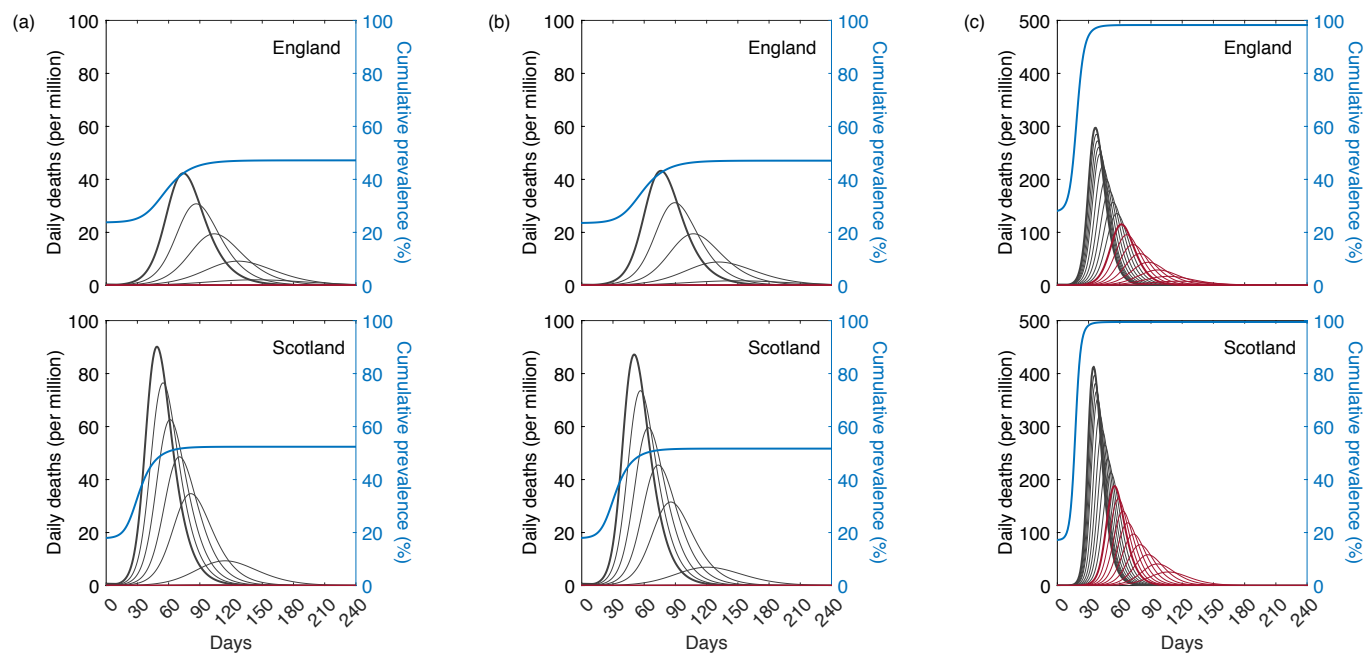

Fig. 6. Projected SARS-CoV-2 trajectories with $50 \%$ increase in $\mathcal{R}_{0}$ in relation to that estimated for the early phase of the pandemic. Assuming $\mathcal{R}_{\mathrm{c}}(t)=1.5 \cdot \mathcal{R}_{0}$ : without vaccination (black heavy curve) and with a vaccination programme that effectively immunises $8 \%$ of the unvaccinated population per month from February onwards (red heavy curve). Thin lines explore additional vaccination scenarios, from top to bottom (in \% of unvaccinated population per month): $0.5,1,1.5,2,3,4,5,6,7$ (black); 9, 10, 11, 12, 13, 14, 15, 16 (red). Inputed parameter values: $\delta=1 / 4$ per day; $\gamma=1 / 5.5$ per day; $\rho=0.5$; and infection fatality ratio $\mathrm{IFR}=0.9 \%$. (a) Individual variation in susceptibility to infection. (c) Individual variation in exposure to infection. (c) Homogeneous susceptibility and exposure to infection. 
medRxiv preprint doi: https://doi.org/10.1101/2021.05.25.21257766; this version posted July 25, 2021. The copyright holder for this preprint (which was not certified by peer review) is the author/funder, who has granted medRxiv a license to display the preprint in perpetuity. It is made available under a CC-BY-NC-ND 4.0 International license.

\subsection{Parameter estimation early in the pandemic}

In a pandemic it is important to estimate model parameters early when data series are relatively short. To test the suitability of our methods for that task, we apply the fitting procedure to series of COVID-19 deaths in England and Scotland until 1 July 2020, as Europe was just recovering from the first wave (Fig. 7 and Table 2). The results are remarkably similar to those obtained with longer series above (Figs. 3, 4. 5 and Table 1). As before the heterogeneous models are selected as better models than the homogeneous as they have lower AIC. However the difference is not as great as with larger series and in some situations it may not be possible to discriminate.

As an alternative we run the same fits assuming two scenarios for a fixed ramp of contact restriction relaxation out of lockdown (i.e., $T_{2}$ fixed). The first is motivated by Table 2, where we find the estimated $T_{2}$ to be very large or, equivalently, the ramp to be practically horizontal. Hence we run a scenario where $\mathcal{R}_{\mathrm{c}}(t)$ remains strictly horizontal until the end of the fitting period. The support for the heterogeneous models becomes stronger and the estimated parameters (Table 3) remain similar to when $T_{2}$ was estimated (Table 2). Second we assume a slope such that if maintained $\mathcal{R}_{\mathrm{c}}(t)$ would intersect the original $\mathcal{R}_{0}$ in 120 days (i.e., $T_{2}=120$ days). In this case there is also strong support for the heterogeneous models but the estimated coefficients of variation are larger which is reflected in lower HIT (Table 4).

This suggests that in the eventually of future pandemics these models can be used with similar confidence after one or two waves. Although earlier applications might benefit more from knowledge of time-dependent effects of contact restrictions on transmission this information does not appear critical. 
medRxiv preprint doi: https://doi.org/10.1101/2021.05.25.21257766; this version posted July 25,2021 . The copyright holder for this preprint (which was not certified by peer review) is the author/funder, who has granted medRxiv a license to display the preprint in perpetuity.

Table 2. Model parameters estimated by Bayesian inference based on daily deaths until 1 July 2020 . Model selection based on maximum log-likelihood (LL) and Akaike information criterion (AIC). Best fitting models have lower AIC scores. Infection fatality ratio, IFR $=0.9 \%$. $\mathcal{H}_{0}$, calculated from $\mathcal{R}_{0}$ and $C V$ using formulas (12) or (19), as appropriate.

\begin{tabular}{|c|c|c|c|c|c|c|}
\hline & \multicolumn{2}{|c|}{ Heterogeneous susceptibility } & \multicolumn{2}{|c|}{ Heterogeneous connectivity } & \multicolumn{2}{|c|}{ Homogeneous } \\
\hline & Median & $95 \% \mathrm{CI}$ & Median & $95 \%$ CI & Median & $95 \%$ CI \\
\hline \multicolumn{7}{|c|}{ Common parameters } \\
\hline$c_{1}$ & 0.25 & $(0.23,0.27)$ & 0.25 & $(0.23,0.27)$ & 0.23 & $(0.22,0.24)$ \\
\hline$\eta$ & 15 & $(15,15)$ & 15 & $(15,15)$ & 15 & $(15,15)$ \\
\hline$C V$ & 1.42 & $(0.96,1.81)$ & 0.99 & $(0.43,1.28)$ & 0 & - \\
\hline \multicolumn{7}{|c|}{ England } \\
\hline$T_{0}$ & 0.65 & $(0.03,42.30)$ & 0.61 & $(0.03,2.77)$ & 2.27 & $(0.23,4.45)$ \\
\hline$T_{2}$ & $1.99 \cdot 10^{5}$ & $\left(1.19 \cdot 10^{3}, 7.00 \cdot 10^{7}\right)$ & $7.42 \cdot 10^{5}$ & $\left(1.63 \cdot 10^{3}, 7.95 \cdot 10^{7}\right)$ & $9.78 \cdot 10^{5}$ & $\left(4.45 \cdot 10^{3}, 8.08 \cdot 10^{7}\right)$ \\
\hline $\mathcal{R}_{0}$ & 3.43 & $(3.31,3.49)$ & 3.43 & $(3.28,3.49)$ & 3.31 & $(3.16,3.48)$ \\
\hline $\mathcal{H}_{0}$ & $34 \%$ & $(24 \%, 48 \%)$ & $34 \%$ & $(24 \%, 60 \%)$ & $70 \%$ & $(68 \%, 71 \%)$ \\
\hline \multicolumn{7}{|c|}{ Scotland } \\
\hline$T_{0}$ & 12.50 & $(10.87,12.98)$ & 12.48 & $(10.78,12.98)$ & 12.45 & $(10.34,12.98)$ \\
\hline$T_{2}$ & $1.28 \cdot 10^{5}$ & $\left(3.55 \cdot 10^{2}, 6.35 \cdot 10^{7}\right)$ & $4.35 \cdot 10^{5}$ & $\left(4.09 \cdot 10^{2}, 6.84 \cdot 10^{7}\right)$ & $3.82 \cdot 10^{5}$ & $\left(5.83 \cdot 10^{2}, 7.25 \cdot 10^{7}\right)$ \\
\hline $\mathcal{R}_{0}$ & 3.37 & $(3.31,3.46)$ & 3.37 & $(3.31,3.46)$ & 3.37 & $(3.30,3.51)$ \\
\hline $\mathcal{H}_{0}$ & $33 \%$ & $(25 \%, 47 \%)$ & $34 \%$ & $(24 \%, 60 \%)$ & $70 \%$ & $(70 \%, 71 \%)$ \\
\hline \multicolumn{7}{|c|}{ Model selection } \\
\hline $\mathrm{LL}$ & & -900.40 & & -899.60 & & -909.89 \\
\hline $\mathrm{AIC}$ & & 1818.80 & & 1817.20 & & 1835.80 \\
\hline
\end{tabular}

Table 3. Model parameters estimated by Bayesian inference based on daily deaths until 1 July 2020, assuming constant $\mathcal{R}_{\mathrm{c}}(t)$ from the first lockdown onwards (i.e. $T_{2} \rightarrow \infty$ ). Model selection based on maximum log-likelihood (LL) and Akaike information criterion (AIC). Best fitting models have lower $\mathrm{AIC}$ scores. Infection fatality ratio, IFR $=0.9 \% . \mathcal{H}_{0}$, calculated from $\mathcal{R}_{0}$ and $C V$ using formulas (12) or (19), as appropriate.

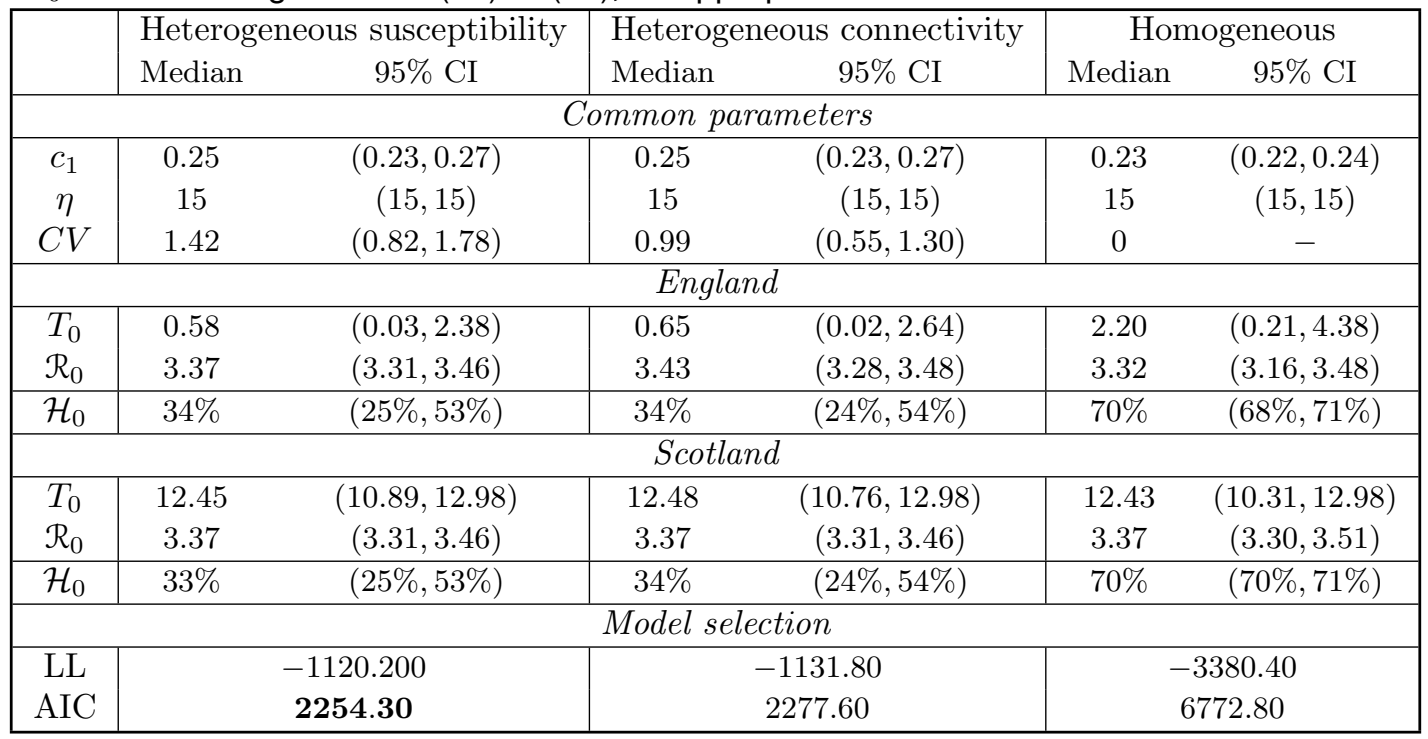


medRxiv preprint doi: https://doi.org/10.1101/2021.05.25.21257766; this version posted July 25, 2021. The copyright holder for this preprint (which was not certified by peer review) is the author/funder, who has granted medRxiv a license to display the preprint in perpetuity. It is made available under a CC-BY-NC-ND 4.0 International license.

(a)
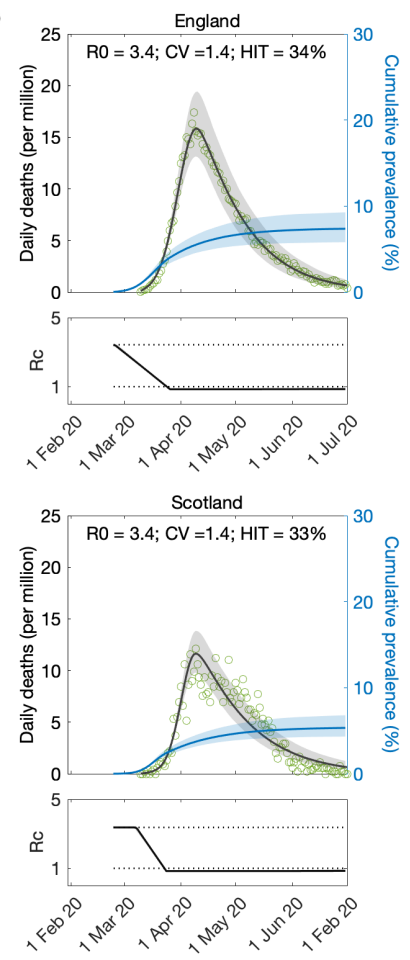

(b)
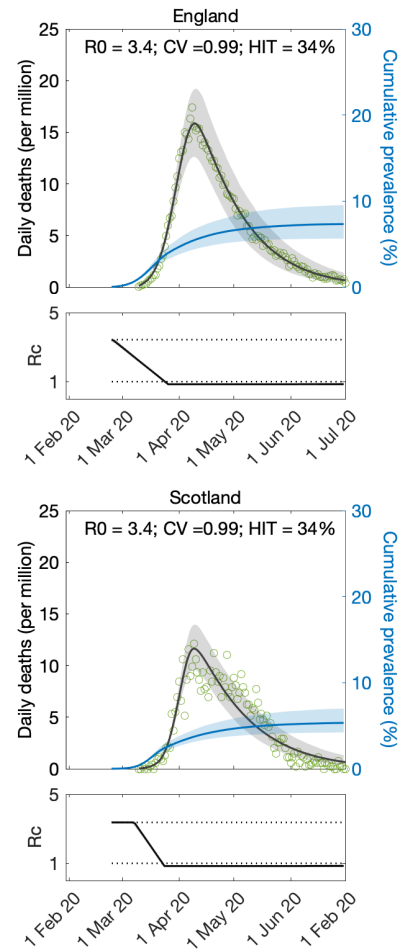

(c)
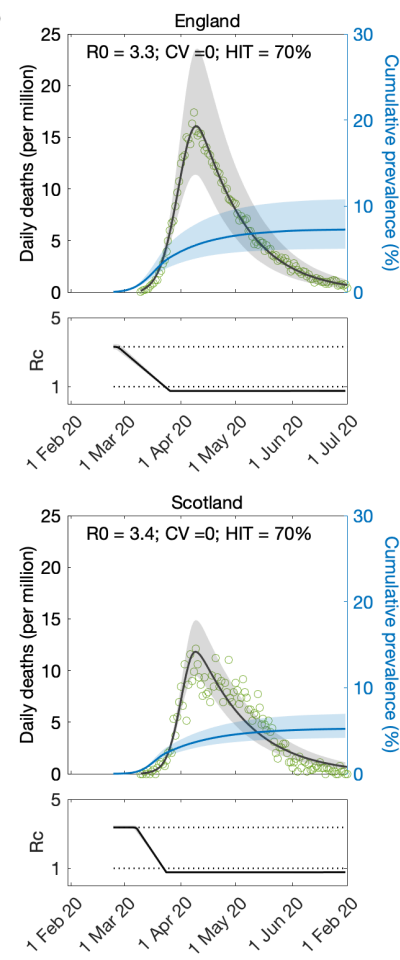

Fig. 7. Model-based estimates based on first wave of SARS-CoV-2 pandemic. Modelled trajectories of COVID-19 deaths (black) and cumulative percentage infected (blue). Dots are data for daily reported deaths. Basic reproduction numbers under control $\left(\mathcal{R}_{\mathrm{c}}\right)$ are displayed on shallow panels underneath the main plots. Inputed parameter values: $\delta=1 / 4$ per day; $\gamma=1 / 5.5$ per day; $\rho=0.5$; and infection fatality ratio IFR $=0.9 \%$. Inicial basic reproduction numbers, coefficients of variation and control parameters estimated by Bayesian inference (estimates in Table 2). Fitted curves represent best fitting trajectories and shades are $95 \%$ credible intervals generated from 100,000 posterior samples. (a) Individual variation in susceptibility to infection. (c) Individual variation in exposure to infection. (c) Homogeneous susceptibility and exposure to infection. 
medRxiv preprint doi: https://doi.org/10.1101/2021.05.25.21257766; this version posted July 25,2021 . The copyright holder for this preprint (which was not certified by peer review) is the author/funder, who has granted medRxiv a license to display the preprint in perpetuity.

It is made available under a CC-BY-NC-ND 4.0 International license .

Table 4. Model parameters estimated by Bayesian inference based on daily deaths until 1 July 2020, assuming that after the first lockdown $\mathcal{R}_{\mathrm{c}}(t)$ begins a gradual return to the baseline $\mathcal{R}_{0}$ at a fixed rate $\left(T_{2}=120\right.$ days in this case). Model selection based on maximum log-likelihood (LL) and Akaike information criterion (AIC). Best fitting models have lower AIC scores. Infection fatality ratio, $\mathrm{IFR}=0.9 \%$. $\mathcal{H}_{0}$, calculated from $\mathcal{R}_{0}$ and $C V$ using formulas (12) or (19), as appropriate.

\begin{tabular}{|c|c|c|c|c|c|c|}
\hline & \multicolumn{2}{|c|}{ Heterogeneous susceptibility } & \multicolumn{2}{|c|}{ Heterogeneous connectivity } & \multicolumn{2}{|c|}{ Homogeneous } \\
\hline & Median & $95 \%$ CI & Median & $95 \%$ CI & Median & $95 \% \mathrm{CI}$ \\
\hline \multicolumn{7}{|c|}{ Common parameters } \\
\hline$c_{1}$ & 0.31 & $(0.30,0.33)$ & 0.32 & $(0.30,0.35)$ & 0.24 & $(0.23,0.24)$ \\
\hline$\eta$ & 15 & $(15,15)$ & 14 & $(13,15)$ & 17 & $(17,17)$ \\
\hline$C V$ & 2.53 & $(2.38,2.66)$ & 1.86 & $(1.70,2.07)$ & 0 & - \\
\hline \multicolumn{7}{|c|}{ England } \\
\hline$T_{0}$ & 0.21 & $(0.00,1.08)$ & 0.18 & $(0.01,0.97)$ & 5.48 & $(4.02,6.78)$ \\
\hline $\mathcal{R}_{0}$ & 3.44 & $(3.38,3.47)$ & 3.47 & $(3.39,3.56)$ & 3.02 & $(2.94,3.11)$ \\
\hline $\mathcal{H}_{0}$ & $15 \%$ & $(14 \%, 17 \%)$ & $15 \%$ & $(12 \%, 17 \%)$ & $67 \%$ & $(66 \%, 68 \%)$ \\
\hline \multicolumn{7}{|c|}{ Scotland } \\
\hline$T_{0}$ & 12.75 & $(11.98,12.99)$ & 12.79 & $(12.13,12.99)$ & 12.60 & $(11.32,12.99)$ \\
\hline $\mathcal{R}_{0}$ & 3.31 & $(3.26,3.36)$ & 3.33 & $(3.27,3.41)$ & 3.23 & $(3.19,3.30)$ \\
\hline $\mathcal{H}_{0}$ & $15 \%$ & $(14 \%, 17 \%)$ & $14 \%$ & $(12 \%, 17 \%)$ & $69 \%$ & $(69 \%, 70 \%)$ \\
\hline \multicolumn{7}{|c|}{ Model selection } \\
\hline $\mathrm{LL}$ & & -951.70 & & 960.54 & & 307.80 \\
\hline $\mathrm{AIC}$ & & 1917.40 & & 935.10 & & 27.70 \\
\hline
\end{tabular}


medRxiv preprint doi: https://doi.org/10.1101/2021.05.25.21257766; this version posted July 25 , 2021 . The copyright holder for this preprint

(which was not certified by peer review) is the author/funder, who has granted medRxiv a license to display the preprint in perpetuity.

It is made available under a CC-BY-NC-ND 4.0 International license .

Frailty variation SEIR models applied to SARS-CoV-2

\subsection{Coefficients of variation from contact surveys}

Contact patterns provide one of the easiest sources of heterogeneity to study directly. One approach is to use large-scale diary experiments to collect self-reported logs of close or physical contact from study participants. In this section we show data from several of these contact-pattern studies, listed in Table 5. In Fig. 8 we show gamma-fits for the contact distribution of each study on a log scale, along with the CV for each empirical distribution. These empirically measured contact distributions reveal CV between 0.7 and 1.5 (depending on study and setting).

In addition to the magnitude of individual variation in connectivity, the time scale of that variation is another important determinant of the effect of selection in accelerating the acquisition of population immunity (Tkachenko et al. 2021). The referenced studies typically report contact patterns for individuals over a very short (e.g., 1-day) period which is insufficient for assessing persistence of the measured variation. One of the studies (Hens et al. 2009) made an extra step and measured contact patterns for each individual on two different days (one weekday and one weekend day). In Fig. 9, we show fits for contact patterns by these two days individually, and for the average. The CV for the contact heterogeneity that persists over the two days is approximately 1.1 (in contrast with the larger 1.4 or 1.6 for each day alone).

For a heterogeneous model of an epidemic which unfolds over a timescale like a year, local dynamics are driven by assumptions about heterogeneity in short-term (e.g., week-long) averages in contact patterns, while global dynamics depend on assumptions about persistence of heterogeneity in those short-term averages over the timescale of the simulation. However, these long-term averages are frequently not evaluated directly by contact diary experiments.

One way to estimate persistent contact heterogeneity from below is to bin contact data by age groups. For example, heterogeneity in contact patterns which persists in contact data after binning in 5-year age groups represents population-level heterogeneity in contact patterns that is persistent on multi-year time scales. Of course, this approach only captures heterogeneity mediated by age; i.e., it would only capture the full extent of heterogeneity in contact patterns if there was no within-age-group variation in contact patterns. As such we should expect age-binned contact data to underestimate the level of persistent heterogeneity in contact patterns (Britton et al. 2020), perhaps quite substantially. In Fig. 10 we show the effect on CV of binning the data from the studies in Table 5 in 1- and 10-year age groups, respectively. Generally, binning by larger periods tends to reduce heterogeneity substantially.

There have also been detailed studies that specifically measure mobility which suggest higher levels of individual variation in number of contacts (Eubank et al. 2004).

An entirely different approach to measure heterogeneity is to trace contacts of infected individuals and count how many secondary infections each has caused. Adam et al (Adam et al. 2020) conducted such contact tracing in Hong Kong and estimated a coefficient of variation of 2.5. This is expected to measure more variation as it captures infectiousness as well. The question remains as how persistent this variation is and hence 
medRxiv preprint doi: https://doi.org/10.1101/2021.05.25.21257766; this version posted July 25,2021 . The copyright holder for this preprint (which was not certified by peer review) is the author/funder, who has granted medRxiv a license to display the preprint in perpetuity.

It is made available under a CC-BY-NC-ND 4.0 International license.
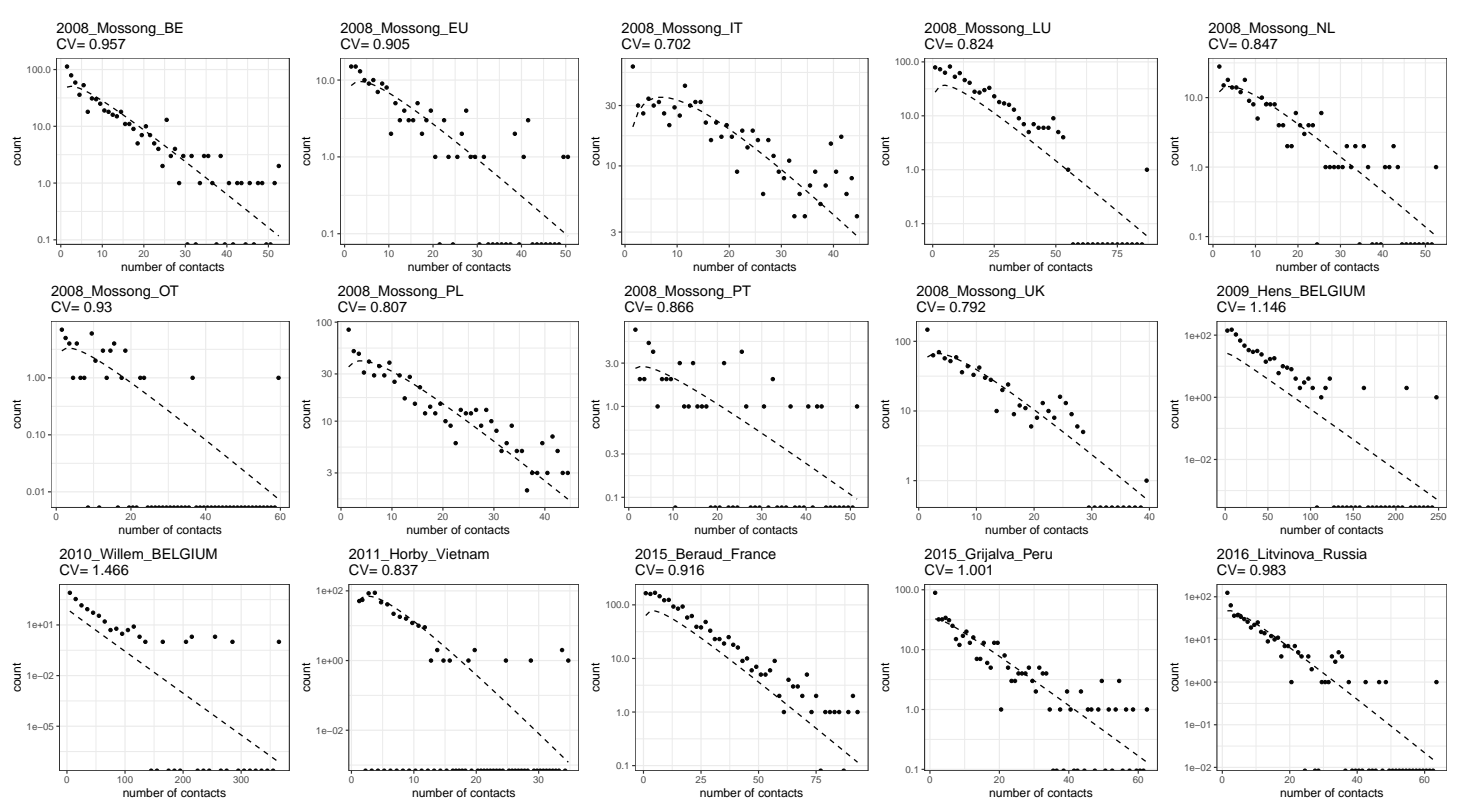

2015 Beraud_France
$\mathrm{CV}=0.916$

2015 Grijalva Peru
$\mathrm{CV}=\overline{1} .001$
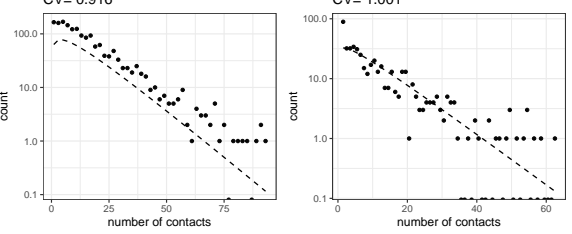

2017 Leung_HongKong
$\mathrm{CV}=1.274$

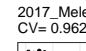

2019 ZZhang_China
$\mathrm{CV}=\overline{0} .909$
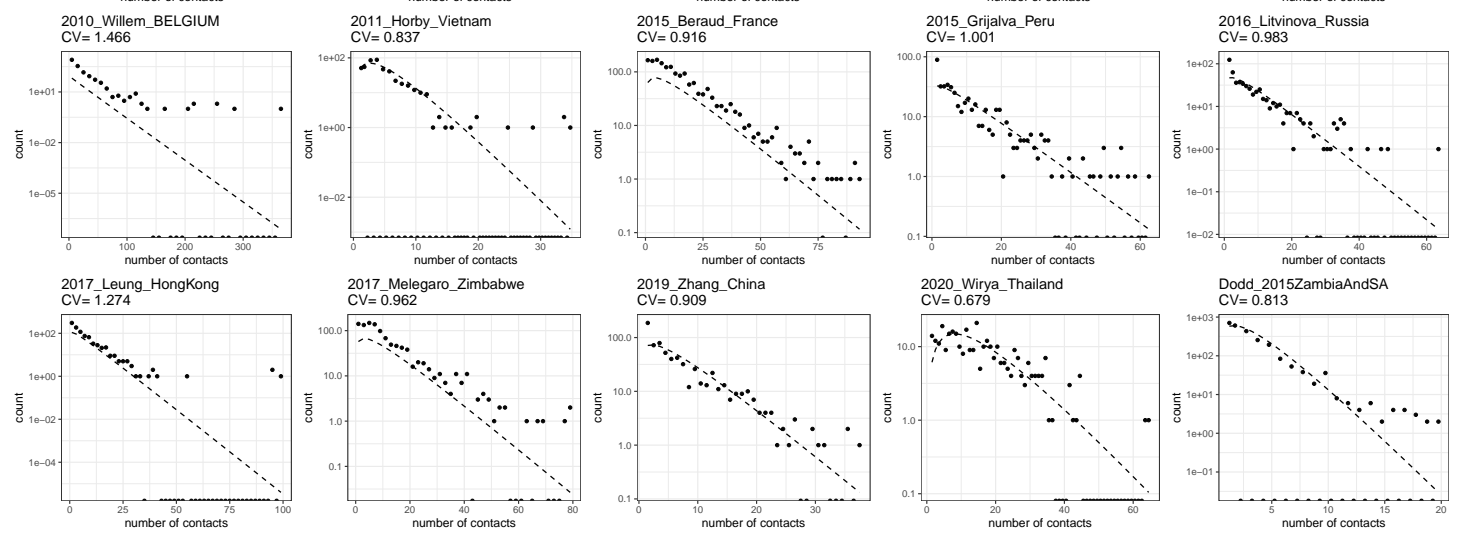

Fig. 8. Gamma fits for the included contact surveys.
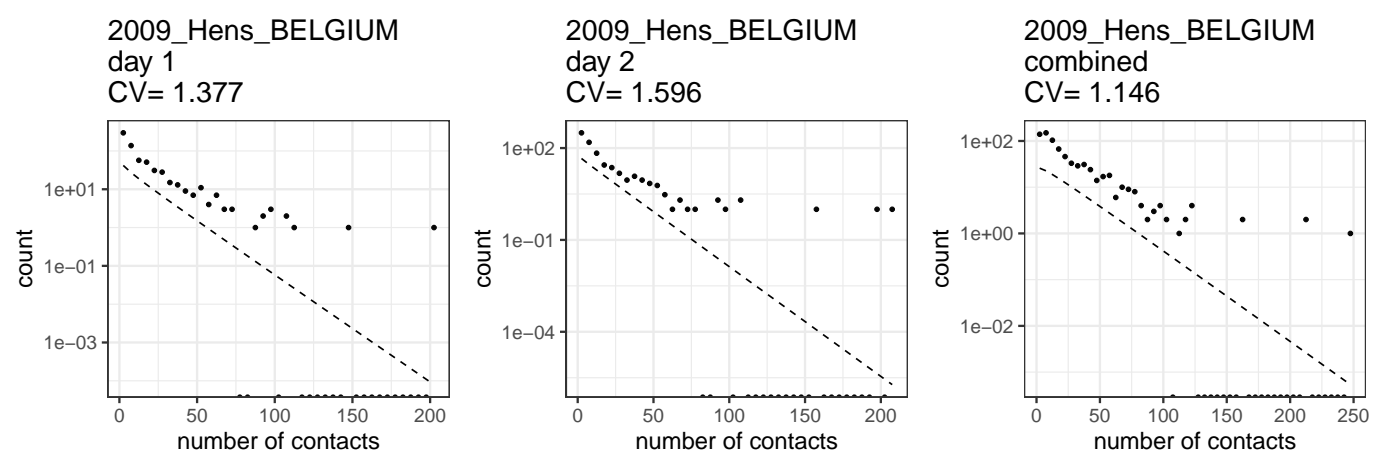

Fig. 9. Persistence of contact heterogeneity. When averaged over two separate diary days the contact distribution CV is $17-28 \%$ lower. 
medRxiv preprint doi: https://doi.org/10.1101/2021.05.25.21257766; this version posted July 25,2021 . The copyright holder for this preprint (which was not certified by peer review) is the author/funder, who has granted medRxiv a license to display the preprint in perpetuity.

It is made available under a CC-BY-NC-ND 4.0 International license.

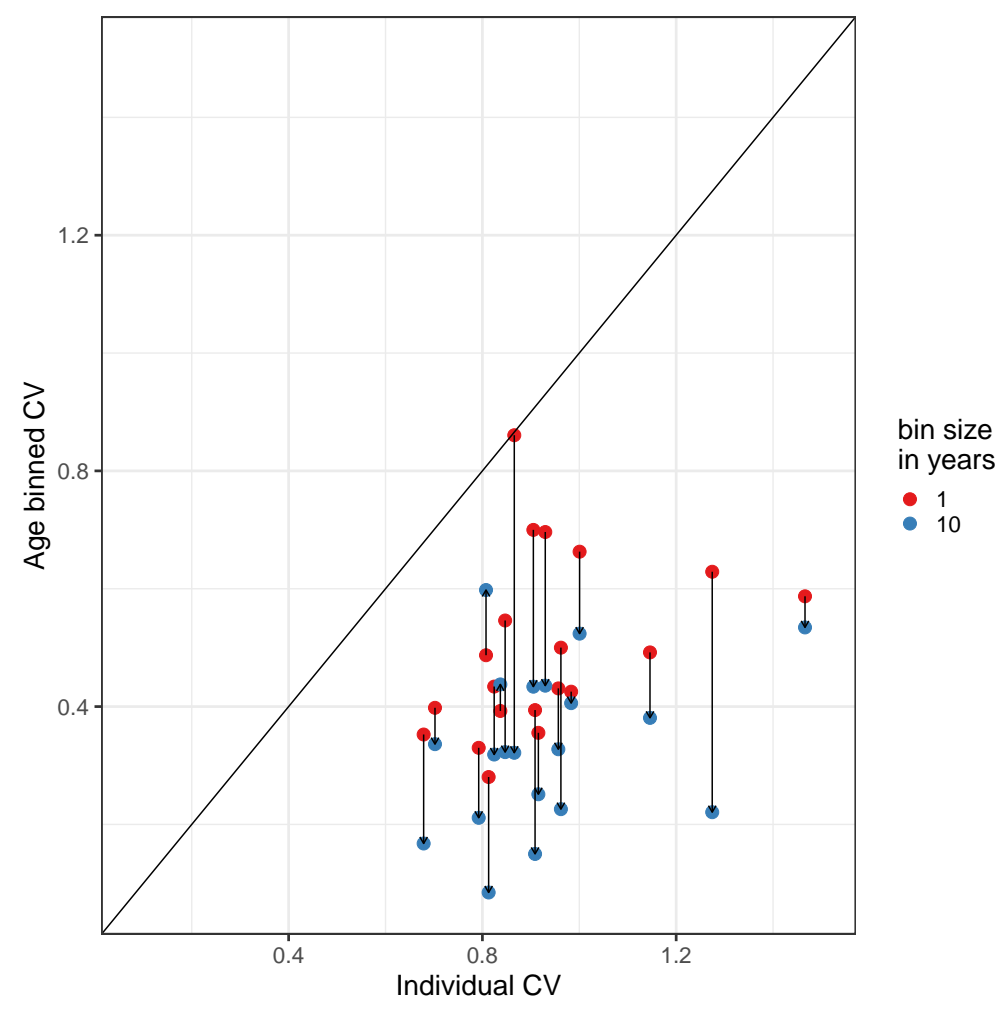

Fig. 10. Binning by age. 
medRxiv preprint doi: https://doi.org/10.1101/2021.05.25.21257766; this version posted July 25 , 2021 . The copyright holder for this preprint (which was not certified by peer review) is the author/funder, who has granted medRxiv a license to display the preprint in perpetuity.

It is made available under a CC-BY-NC-ND 4.0 International license .

Table 5. Contact pattern studies.

\begin{tabular}{|rll|}
\hline & Dataset & citation \\
\hline 2 & 2008_Mossong_BE & (Mossong et al. 2008) \\
3 & 2008_Mossong_EU & (Mossong et al. 2008) \\
4 & 2008_Mossong_IT & (Mossong et al. 2008) \\
5 & 2008_Mossong_LU & (Mossong et al. 2008) \\
6 & 2008_Mossong_OT & (Mossong et al. 2008) \\
7 & 2008_Mossong_PL & (Mossong et al. 2008) \\
8 & 2008_Mossong_PT & (Mossong et al. 2008) \\
9 & 2008_Mossong_UK & (Mossong et al. 2008) \\
10 & 2009_Hens_BELGIUM & (Mossong et al. 2008) \\
11 & 2010_Willem_BELGIUM et al. 2009) & (Willem et al. 2012) \\
12 & 2011_Horby_Vietnam & (Horby et al. 2011) \\
13 & 2015_Beraud_France & (Beraud et al. 2015) \\
14 & 2015_Grijalva_Peru & (Grijalva et al. 2015) \\
15 & 2016_Litvinova_Russia & (Litvinova et al. 2019) \\
16 & 2017_Leung_HongKong & (Leung et al. 2017) \\
17 & 2017_Melegaro_Zimbabwe & (Melegaro et al. 2017) \\
18 & 2019_Zhang_China & (Zhang et al. 2020) \\
19 & 2020_Mahikul_Thailand & (Mahikul et al. 2020) \\
20 & 2015_Dodd_ZambiaAndSA & (Dodd et al. 2015) \\
\hline
\end{tabular}

how responsive to selection.

Our model-based inference of persistent heterogeneity based on epidemic trajectories indicates $C V=1.1$ for England and Scotland (Table 1, heterogeneous connectivity) which appears generally consistent with what is currently available from empirical studies. This level of individual variation lies above that inputed in common epidemic models (whether compartmental or individual-based) that implement contact heterogeneity reduced to 5-year averages and below estimates based on contact tracing which combine the effects of heterogeneity in infectiousness.

\section{Conclusion}

For over a century, mathematical epidemiologists have realised that individual variation in susceptibility and exposure to infection are key determinants of the shape of epidemic curves. Models that underrepresent these forms of variation tend to overpredict epidemic sizes and consequently inflate the effects attributed to control measures. Infectious disease models can include many interacting processes, informed by many data sources, to aid understanding of epidemic dynamics but complexity does not necessarily make them more suitable for predictive purposes. Predictive ability in population dynamics is critically dependent on the complete account of forms of heterogeneity that are under selection. In infectious disease the most impactful selection is that exerted by the force of infection on individual susceptibility and exposure.

With the aim of capturing heterogeneity in full we opted for simple model formalisms with inbuilt distributions of susceptibility or exposure in such a way that we could seek 
medRxiv preprint doi: https://doi.org/10.1101/2021.05.25.21257766; this version posted July 25,2021 . The copyright holder for this preprint (which was not certified by peer review) is the author/funder, who has granted medRxiv a license to display the preprint in perpetuity.

It is made available under a CC-BY-NC-ND 4.0 International license.

to estimate coefficients of variation by fitting to epidemic curves. We have used the COVID-19 pandemic to test the approach as epidemic trajectories unfold. We estimate final sizes of unmitigated epidemics to be less than half those predicated by studies based on homogeneous models, which is naturally linked to lower herd immunity thresholds. Homogeneous models with realistic vaccination rates also fail to reproduce the low levels of infection and deaths registered over recent months in England and Scotland.

We estimate coefficients of variation consistent with a panoply of empirical studies of contact patterns resulting in herd immunity thresholds by natural infection around $30 \%$, in England and Scotland. Given that vaccination is also contributing to immunisation, herd immunity thresholds are reached with lower infected percentages. Based on forward simulations with a range of vaccination scenarios we conclude HIT is close to being achieved in both nations, with a lower infection burden and greater contribution of vaccination in Scotland. Several countries in Europe and America are in similar situations (Washburne et al. 2021) and may be in a comfortable position to redirect vaccines to more susceptible countries.

\section{Acknowledgements}

We thank Rodrigo Corder and Antonio Montalbán for valuable discussions throughout this study.

\section{References}

[Aalen 1988] Aalen, O. O. (1988) Heterogeneity in survival analysis. Stat. Med., 7, 11211137.

[Aalen et al. 2015] Aalen, O. O., Valberg, M., Grotmol, T. and Tretli, S. (2015) Understanding variation in disease risk: the elusive concept of frailty. Int. J. Epidemiol., 4, 1408-1421.

[Adam et al. 2020] Adam, D. C., Wu, P., Wong, J. Y., Lau, E. H. Y., Tsang, T. K., Cauchemez, S., et al. (2020) Clustering and superspreading potential of SARSCoV-2 infections in Hong Kong. Nat. Med., 26, 1714-1719.

[Aguas et al. 2020] Aguas, R., Corder, R. M., King, J. G., Gonçalves, G., Ferreira, M. U. and Gomes, M. G. M. (2020) Herd immunity thresholds for SARS-CoV-2 estimated from unfolding epidemics. Preprint medRxiv: 10.1101/2020.07.23.20160762.

[Arons et al. 2020] Arons, M. M., Hatfield, K. M., Reddy, S. C., Kimball, A., James, A., Jacobs, et al. (2020) Public Health-Seattle and King County and CDC COVID-19 Investigation Team. Presymptomatic SARS-CoV-2 infections and transmission in a skilled nursing facility. N. Engl. J. Med., 382, 2081-2090.

[Ball 1985] Ball, F. (1985) Deterministic and stochastic epidemic models with several kinds of susceptibles. Adv. Appl. Probab., 17, 1-22. 
medRxiv preprint doi: https://doi.org/10.1101/2021.05.25.21257766; this version posted July 25,2021 . The copyright holder for this preprint (which was not certified by peer review) is the author/funder, who has granted medRxiv a license to display the preprint in perpetuity.

It is made available under a CC-BY-NC-ND 4.0 International license.

[Beraud et al. 2015] Béraud, G., Kazmercziak, S., Beutels, P., Levy-Bruhl, D., Lenne, X., Mielcarek, N., et al. (2015) The French connection: the first large populationbased contact survey in France relevant for the spread of infectious diseases. PLOS One, 10, e0133203.

[Britton et al. 2020] Britton, T., Ball, F. and Trapman, P. (2020) A mathematical model reveals the influence of population heterogeneity on herd immunity to SARS-CoV-2. PLOS One, 369, 846-849.

[Colombo et al. 2020] Colombo, M., Mellor, J., Colhoun, H. M., Gomes, M. G. M. and McKeigue, P. M. (2020) Trajectory of COVID-19 epidemic in Europe. Preprint medRxiv: 10.1101/2020.09.26.2020226\%.

[Coutinho et al. 1999] Coutinho, F. A. B., Massad, E., Lopez, L. F., Burattini, M. N., Struchiner, C. J. and Azevedo-Neto, R. S. (1999) Modelling heterogeneities in individual frailties in epidemic models. Math. Comput. Model., 30, 97-115.

[Davies et al. 2021] Davies, N. G., Abbott, S., Barnard, R. C., Jarvis, C. I., Kucharski, A. J., Munday, J. D., et al. (2021) Estimated transmissibility and impact of SARSCoV-2 lineage B.1.1.7 in England. Science, 372, eabg3055.

[Diekmann et al. 2013] Diekmann, O., Heesterbeek, H. and Britton, T. (2013) Mathematical Tools for Understanding Infectious Disease Dynamics. Princeton University Press, Princeton, New Jersey.

[Dodd et al. 2015] Dodd, P. J., Looker, C., Plumb, I. D., Bond, V., Schaap, A., Shanaube, K., et al. (2015) Age-and sex-specific social contact patterns and incidence of Mycobacterium tuberculosis infection. Am. J. Epidemiol., 2, 156-166.

[Dwyer et al. 1997] Dwyer, G., Elkinton, J. S. and Buonaccorsi, J. P. (1997) Host heterogeneity in susceptibility and disease dynamics: Tests of a mathematical model. Am. Nat., 150, 685-707.

[Eubank et al. 2004] Eubank, S., Guclu, H., Kumar, V. S. A., Marathe, M. V., Srinivasan, A., Toroczkai, Z., et al. (2004) Modelling disease outbreaks in realistic urban social networks. Nature, 429, 180-184.

[Finkenstadt and Grenfell 2000] Finkenstadt, B. F. and Grenfell, B. T. (2000) Time series modelling of childhood diseases: a dynamical systems approach. Appl. Statist., 49, 187-205.

[Gart 1968] Gart, J. J. (1968) The mathematical analysis of an epidemic with two kinds of susceptibles. Biometrics, 24, 557-566.

[Gart 1971] Gart, J. J. (1971) The statistical analysis of chain-binomial epidemic models with several kinds of susceptibles. Biometrics, 28, 921-930.

[Gomes et al. 2020] Gomes, M. G. M., Corder, R. M., King, J. G., Langwig, K. E., Souto-Maior, C., Carneiro, J., et al. (2020) Individual variation in susceptibility or exposure to SARS-CoV-2 lowers the herd immunity threshold. Preprint medRxiv: 10.1101/2020.04.27.20081893. 
medRxiv preprint doi: https://doi.org/10.1101/2021.05.25.21257766; this version posted July 25,2021 . The copyright holder for this preprint (which was not certified by peer review) is the author/funder, who has granted medRxiv a license to display the preprint in perpetuity.

It is made available under a CC-BY-NC-ND 4.0 International license.

[Grijalva et al. 2015] Grijalva, C. G., Goeyvaerts, N., Verastegui, H., Edwards, K. M., Gil, A. I., Lanata, C.F ., et al. (2015) A household-based study of contact networks relevant for the spread of infectious diseases in the highlands of Peru. PLOS One, 10, e0118457.

[Hall et al. 2021] Hall, V. J., Foulkes, S., Charlett, A., Atti, A., Monk, E. J., Simmons, R., et al. (2021) SARS-CoV-2 infection rates of antibody-positive compared with antibody-negative health-care workers in England: a large, multicentre, prospective cohort study (SIREN). Lancet, 397, 1459-1469.

[He et al. 2020] He, X., Lau, E. H. Y., Wu, P., Deng, X., Wang, J., Hao, X., et al. (2020) Temporal dynamics in viral shedding and transmissibility of COVID-19. Nat. Med., 26, $672-675$.

[Hens et al. 2009] Hens, N., Goeyvaerts, N., Aerts, M., Shkedy, Z., Van Damme, P. and Beutels, P. (2009) Mining social mixing patterns for infectious disease models based on a two-day population survey in Belgium. BMJ Infect. Dis., 9, 1-18.

[Horby et al. 2011] Horby, P., Thai, P. Q., Hens, N., Yen, N. T. T., Thoang, D. D., Linh, N. M., et al. (2011) Social contact patterns in Vietnam and implications for the control of infectious diseases. PLOS One, 6, e16965.

[Katriel 2012] Katriel, G. (2012) The size of epidemics in populations with heterogeneous susceptibility. J. Math. Biol., 65, 237-262.

[Kermack and McKendrick 1927] Kermack, W. O. and McKendrick, A. G. (1927) A contribution to the mathematical theory of epidemics. Proc. R. Soc. Lond. A, 115, 700-721.

[Kwok et al. 2020] Kwok, K. O., Lai, F., Wei, W. I., Wong, S. Y. S. and Tang, J. (2020) Herd immunity - estimating the level required to halt the COVID-19 epidemics in affected countries. J. Infect., 80, e32-e33.

[Lauer et al. 2020] Lauer, S. A., Grantz, K. H., Bi, Q., Jones, F. K., Zheng, Q., Meredith, H. R., Azman, A. S., et al. (2020) The incubation period of coronavirus disease 2019 (COVID-19) from publicly reported confirmed cases: estimation and application. Ann. Intern. Med., 172, 577-582.

[Leung et al. 2017] Leung, K., Jit, M., Lau, E. H. Y. and Wu, J. Y. (2017) Social contact patterns relevant to the spread of respiratory infectious diseases in Hong Kong. Sci. Rep, 7, 1-12.

[Li et al. 2020] Li, Q., Guan, X., Wu, P., Wang, X., Zhou, L., Tong, Y., et al. (2020) Early transmission dynamics in Wuhan, China, of novel coronavirus-infected pneumonia. N. Engl. J. Med., 382, 1199-1207.

[Litvinova et al. 2019] Litvinova, M., Liu, Q.-H., Kulikov, E. S., Evgeny, S. and Ajelli. M. (2019) Reactive school closure weakens the network of social interactions and reduces the spread of influenza. Proc. Natl. Acad. Sci. U.S.A., 27, 13174-13181. 
medRxiv preprint doi: https://doi.org/10.1101/2021.05.25.21257766; this version posted July 25,2021 . The copyright holder for this preprint (which was not certified by peer review) is the author/funder, who has granted medRxiv a license to display the preprint in perpetuity.

It is made available under a CC-BY-NC-ND 4.0 International license.

[McKendrick 1939] McKendrick, A. G. (1939) The dynamics of crowd infection. Edinb. Med. J., 47, 117-136.

[Mahikul et al. 2020] Mahikul, W., Kripattanapong, S., Hanvoravongchai, P., Meeyai, A., Iamsirithaworn, S., Auewarakul, P., et al. (2020) Contact Mixing Patterns and Population Movement among Migrant Workers in an Urban Setting in Thailand. Int. J. Environ. Res. Public Health, 17, 2237.

[McAloon et al. 2020] McAloon, C., Collins, A., Hunt, K., Barber, A., Byrne, A. W., Butler, F., et al. (2020) Incubation period of COVID-19: a rapid systematic review and meta-analysis of observational research. BMJ Open, 10, e039652.

[Melegaro et al. 2017] Melegaro, A., Del Fava, E., Poletti, P., Merler, S., Nyamukapa, C., Williams, J., et al. (2017) Social contact structures and time use patterns in the Manicaland Province of Zimbabwe. PLOS One, 12, e0170459.

[Miller et al. 2012] Miller, J. C., Slim, A. C. and Volz, E. M. (2012) Edge-based compartmental modelling for infectious disease spread. J. R. Soc. Interface, 9, 890-906.

[Montalbán et al. 2020] Montalbán, A., Corder, R. M. and Gomes, M. G. M. (2020) Herd immunity under individual variation and reinfection. Preprint arXiv:2008.00098v2.

[Mossong et al. 2008] Mossong, J., Hens, N., Jit, M., Beutels, P., Auranen, K., Mikolajczyk, R., et al. (2008) Social contacts and mixing patterns relevant to the spread of infectious diseases. PLOS Med., 5, e74.

[Nishiura et al. 2020] Nishiura, H., Linton, N. M. and Akhmetzhanov, A. R. (2020) Serial interval of novel coronavirus (COVID-19) infections. Int. J. Infect. Dis., 93, 284-286.

[Novozhilov 2008] Novozhilov, A. S. (2008) On the spread of epidemics in a closed heterogeneous population. Math. Biosci., 215, 177-185.

[Pastor-Satorras and Vespignani 2001] Pastor-Satorras, R. and Vespignani, A. (2001) Epidemic dynamics and endemic states in complex networks. Phys. Rev. E, 63, 066117 .

[Richard et al. 2021] Richard, D., Shaw, L. P., Lanfear, R., Acman, M., Owen, C.J., Tan, C. C. S., et al. (2021) A phylogeny-based metric for estimating changes in transmissibility from recurrent mutations in SARS-CoV-2. Preprint bioRxiv: 10.1101/2021.05.06.442903.

[Stapor et al. 2018] Stapor, P., Weindl, D., Ballnus, B., Hug, S., Loos, C., Fiedler, A., et al. (2018) PESTO: Parameter EStimation TOolbox. Bioinformatics, 34, 705-707.

[Tkachenko et al. 2021] Tkachenko, A. V., Maslov, S., Elbanna, A., Wong, G. N., Weiner, Z. J. and Goldenfeld, N. (2021) Time-dependent heterogeneity leads to transient suppression of the COVID-19 epidemic, not herd immunity. Proc. Natl. Acad. Sci. U. S. A., 118, e2015972118. 
medRxiv preprint doi: https://doi.org/10.1101/2021.05.25.21257766; this version posted July 25, 2021. The copyright holder for this preprint (which was not certified by peer review) is the author/funder, who has granted medRxiv a license to display the preprint in perpetuity.

[To et al. 2020] To, K. K., Tsang, O. T., Leung, W. S., Tam, A. R., Wu, T. C., Lung, D. C., et al. (2020) Temporal profiles of viral load in posterior oropharyngeal saliva samples and serum antibody responses during infection by SARS-CoV-2: an observational cohort study. Lancet Infect. Dis., 20, 565-574.

[Vaupel et al. 1979] Vaupel, J. H., Manton, K. G. and Stallard. E. (1979) The impact of heterogeneity in individual frailty in the dynamics of mortality. Demography, 16, 439-454.

[Volz et al. 2021] Volz, E., Mishra, S., Chand, M., Barrett, J. C., Johnson, R., Geidelberg, L., et al. (2021) Assessing transmissibility of SARS-CoV-2 lineage B.1.1.7 in England. Nature, 10.1038/s41586-021-03470-x.

[Ward et al. 2021] Ward, H., Atchison, C., Whitaker, M., Ainslie, K. E. C., Elliott, J., Okell, L., et al. (2021) SARS-CoV-2 antibody prevalence in England following the first peak of the pandemic. Nat. Commun., 12, 905.

[Washburne et al. 2021] Washburne, A., Silverman, J., Lourenço, J. and Hupert, N. (2021) Analysis and visualization of epidemics on the timescale of burden: derivation and application of Epidemic Resistance Lines (ERLs) to COVID-19 outbreaks in the US. Preprint medRxiv: 10.1101/2021.05.03.21256542.

[Wei et al. 2020] Wei, W. E., Li, Z., Chiew, C. J., Yong, S. E., Toh, M. P. and Lee, V. J. (2020) Presymptomatic transmission of SARS-CoV-2 - Singapore, January 23-March 16, 2020. MMWR Morb. Mortal. Wkly. Rep., 69, 411-415.

[Willem et al. 2012] Willem, L., Van Kerckhove, K., Chao, D.L., Hens, N. and Beutels, P. (2012) A nice day for an infection? Weather conditions and social contact patterns relevant to influenza transmission. PLOS One, 7, e48695.

[Zhang et al. 2020] Zhang, J., Litvinova, M., Wang, W., Wang, Y., Deng, X., Chen, X., et al. (2020) Evolving epidemiology and transmission dynamics of coronavirus disease 2019 outside Hubei province, China: a descriptive and modelling study. Lancet Infect. Dis., 20, 793-802. 